\title{
OUR APPROACH TO THE SPASTIC HIP SUBLUXATION AND DISLOCATION IN CHILDREN WITH CEREBRAL PALSY
}

\author{
Pavel Šponer, David Pellar, Tomáš Kučera, Karel Karpaš
}

Charles University in Prague, Faculty of Medicine in Hradec Králové and University Hospital Hradec Králové, Czech Republic: Department of Orthopaedic Surgery

Summary: The purpose of this study was to evaluate the effectiveness of our approach to the spastic hip subluxation and dislocation in children with cerebral palsy. We evaluated 56 hips in our consecutive patients who had been operated on at our department between January 2003 and December 2005. There were done soft-tissue release procedures in 42 hips, osseous reconstructive surgery in 11 hips and osseous palliative surgery in 3 hips. The duration of follow-ups was 1-3 years after surgery. We achieved good result in 15 hips after soft-tissue release, fifteen hips had a fair result, nine a poor result and three a failure. No redislocation was observed after osseous surgery in our patients. Two patients observed no pain after osseous palliative surgery, transient pain in the hip was in one case. In all hips the range of motion (abduction) was increased. The personal hygiene and possibilities of rehabilitation were improved. Childhood is the optimal time to intervene to maximize the function of the patient with cerebral palsy. The musculoskeletal treatment of the child prevents future problems with pain and deformity.

Key words: Cerebral palsy; Soft-tissue release; Osseous reconstructive surgery; Palliative osteotomy of the femur

\section{Introduction}

Different surgical procedures can be used in the management of spastic hip subluxation and dislocation in children with cerebral palsy. There are two important factors for the indication of the hip surgery. Severity of the hip migration can be evaluated according to Sharrard into four groups: 1. normal or stable hip (the femoral head completely covered by the acetabulum), 2. dysplastic hip (migration percentage <33), 3. subluxated hip (migration percentage 33-99), and 4. dislocated hip (complete loss of the acetabular contact) (12). Prognosis for ambulation is dependent on the geografic type of cerebral palsy (hemiplegia, diplegia, quadriplegia) and on the predicting of ultimate motoric ability according to Vojta $(3,14)$.

The purpose of this study was to evaluate the effectiveness of our approach to the spastic hip subluxation and dislocation in children with cerebral palsy.

\section{Material and Methods}

We evaluated 56 hips in our consecutive patients who had been operated on at our department between January 2003 and December 2005.

The soft-tissue releases were performed in 42 hips. The age of the fourteen spastic diplegia children (27 hips) and eight spastic quadriplegia children (15 hips) at the time of surgery was 3-17 years (the average age 8.6 years). Eleven patients ( 21 hips) were able to walk and eleven patients (21 hips) were unable to walk. There were done these following soft-tissue procedures: open adductor tenotomy in 16, adductor and rectus femoris tenotomy in 18 hip joints, adductor, rectus femoris and iliopsoas tenotomy in 4 hips. Additional rectus femoris tenotomy was used in 4 hip joints.

The osseous reconstructive surgery was done in 11 hips. The age of the six spastic diplegia children (9 hips) and one spastic quadriplegia child (2 hips) at the time of surgery was $1.5-18$ years (the average age 8 years). All these patients (11 hips) were able to walk. There were performed these different surgical procedure: femoral osteotomy in 6, Salter pelvic and femoral osteotomy in 2 hip joints, Steel pelvic osteotomy, open hip reduction with San Diego acetabuloplasty and femoral osteotomy, open hip reduction with femoral shortening and rotational osteotomy in 1 hip joint each.

The osseous palliative surgery was indicated in two spastic quadriplegia children (3 hips) unable to walk. The age at the time of surgery was 10 and 16 years (the average age 14 years).

The duration of follow-ups was 1-3 years after surgery. Each patient underwent a careful clinical examination, and radiografic evaluation at follow-up. Physical examination 
included assessment of the range of the hip joint motion. $\mathrm{X}$-rays included anteroposterior views of the pelvis to assess the severity of the hip migration. All hips after soft-tissue release procedure were classified according to the hip migration percentage into four surgical outcome groups: 1. good (migration percentage <25), 2. fair (migration percentage 25-39), 3. poor (migration percentage 40-60), and 4. failure (migration percentage $>60$ ).

\section{Results}

Fifteen hips (36\%) after soft-tissue release procedure had a good result, fifteen (36\%), a fair result (Fig. 1, 2), nine $(21 \%)$, a poor result, and three $(7 \%)$, a failure. The outcome was unsatisfactory (poor or failure) in older children referred to sotf-tissue release procedure late (Table I).

No redislocation was observed after osseous reconstructive surgery in our patients (Fig. 3, 4). The spastic diplegia patients were able to walk, the spastic quadriplegia patient had a minimal ability to walk.

Two patients observed no pain after osseous palliative surgery, transient pain in the hip was in one case. In all hips the range of motion (abduction) was increased. The perineal care and possibilities of rehabilitation were improved (Fig. 5, 6, 7).

\section{Discussion}

The spastic hip subluxation develops in response to the muscle imbalance (spasticity and contracture of the adductors and flexors of the hip) and spontaneous improvement of the subluxated hip should be never expected. On the contrary a risk of a $10 \%$ increase in the migration percentage per year was reported in the subluxated hip joints (9). The preoperative migration percentage, age at surgery, level of neurological involvement, used surgical technique and oneyear postoperative migration percentage were reported in the literature as predictors of final soft-tissue release procedure outcome $(2,4,6,8,9,13)$. The comparison of outcome results is due to differences among the series difficult, but the rate of satisfactory outcomes (good and fair results) in our patients after soft-tissue-release procedure (72\%) is comparable with other series $(5,8)$.

Soft-tissue procedures alone are not adequate for severe acetabular dysplasia with established subluxation or dislocation of the hip in older child. Because of this limitation of isolated soft-tissue release, a combined soft-tissue release and reconstructive bony procedure have been used for the treatment of severe dysplasia of the hip secondary to neuromuscular disease $(7,10)$. Salter pelvic osteotomy is useful in children with cerebral palsy to 11 years of age only

Tab. 1: Results for 42 hips after soft-tissue release procedure according to the age at the time of the surgery.

\begin{tabular}{|l|c|c|c|}
\hline \multirow{2}{*}{$\begin{array}{l}\text { Age at the time } \\
\text { of the surgery }\end{array}$} & \multicolumn{2}{|c|}{ Surgical outcome group } \\
\cline { 2 - 5 } & $\begin{array}{c}\text { Good } \\
\text { migration percetage }\end{array}$ & $\begin{array}{c}\text { Fair } \\
\text { migration percetage } \\
\text { migration percetage } \\
40-60\end{array}$ & $\begin{array}{c}\text { Failure } \\
\text { migration percetage } \\
>60\end{array}$ \\
\hline To 6 years & $<25$ & $65-39$ & 2 \\
\hline 6 to 12 years & 15 & 6 & 0 \\
\hline Older than 12 years & 0 & 5 & 7 \\
\hline
\end{tabular}

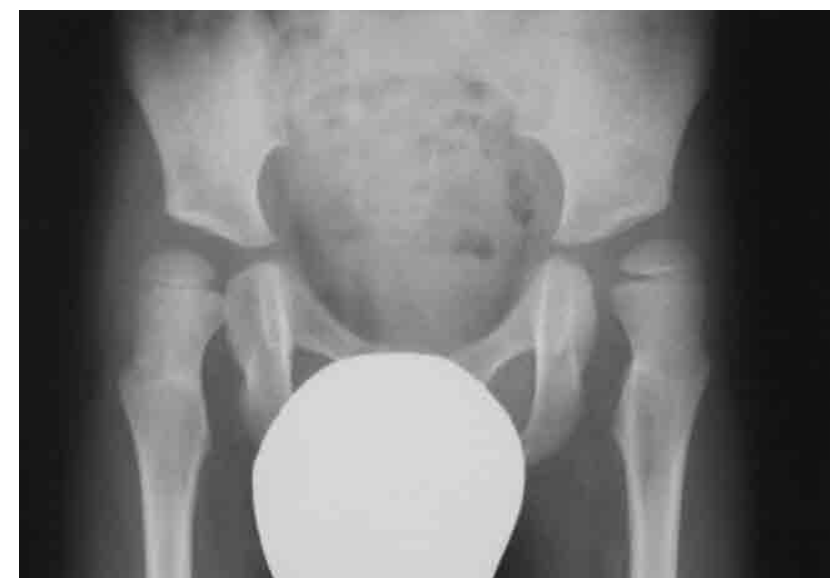

Fig. 1: Radiograph of a four and half-year-old boy with spastic diplegia. The migration percentage was $33 \%$ in the right hip and $38 \%$ in the left hip before the performance of softtissue release bilaterally.

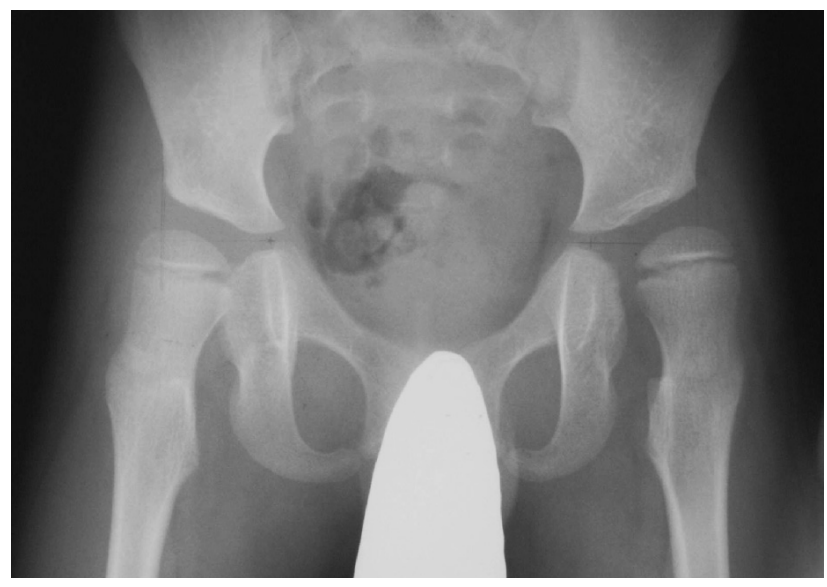

Fig. 2: At one and half year postoperatively, the range of hip abduction was improved bilaterally, the migration percentage was $27 \%$ in the right hip and $33 \%$ in the left hip. Spontaneous increase in the migration percentage was prevented. 


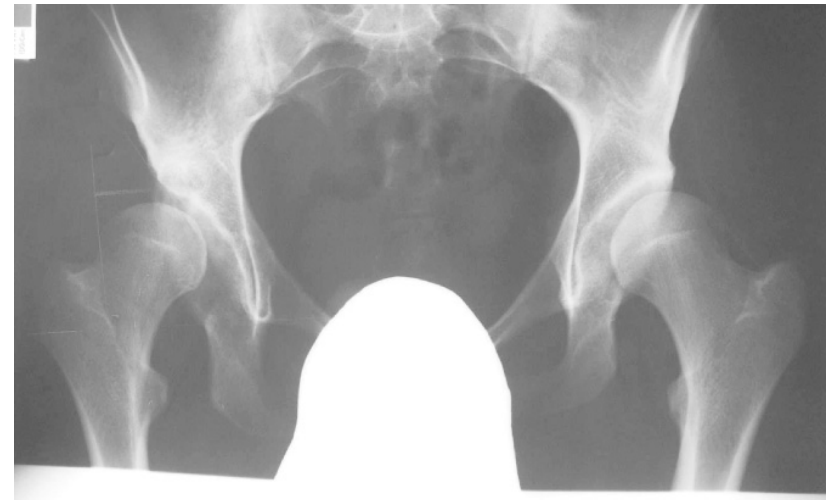

Fig. 3: Anteroposterior radiograph of a seventeen-year-old boy with spastic diplegia who was able to walk. Preoperatively, the right hip was subluxated and painful.

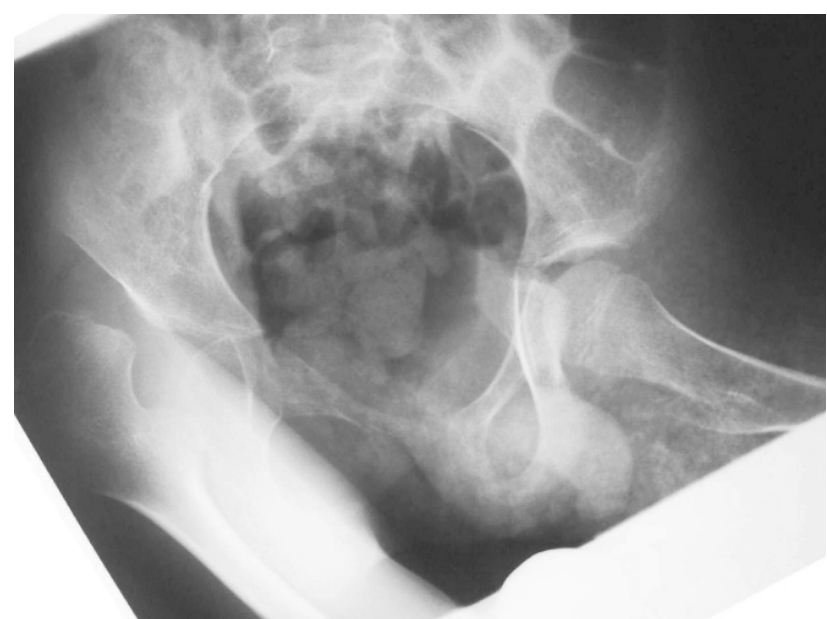

Fig. 5: Radiograph of a ten-year-old boy with spastic quadriplegia who was unable to walk. Preoperatively the right hip with windblown deformity was dislocated and painful.

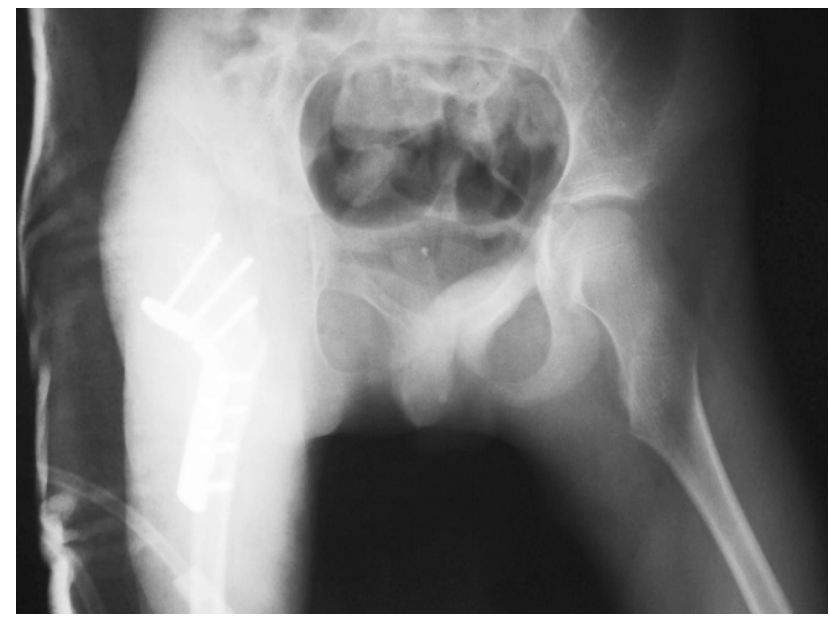

Fig. 6: After the palliative Schanz abduction femoral osteotomy, the range of abduction was increased.

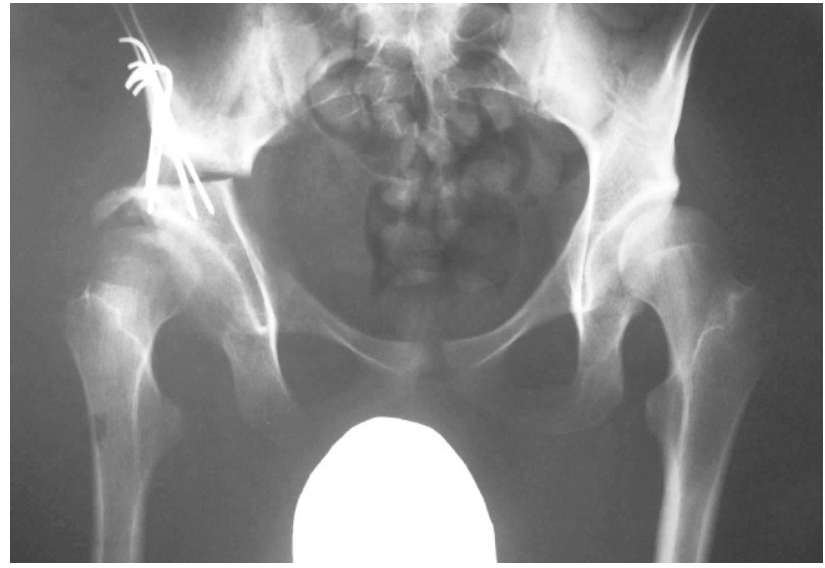

Fig. 4: After Steel triple osteotomy, the right femoral head coverage was much improved and the patient was pain-free.

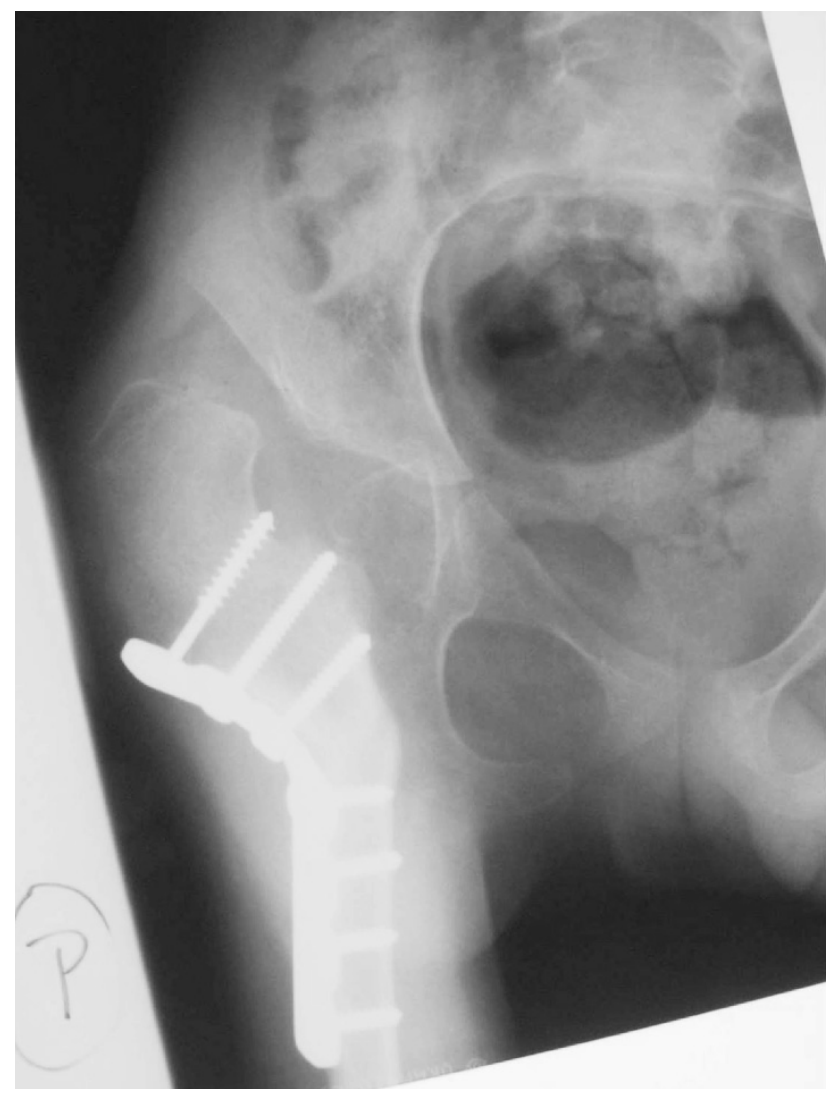

Fig. 7: At one year postoperatively, the personal hygiene and possibilities of rehabilitation were improved. The patient was pain-free. 
when posterior acetabular deficiency is not present and acetabular index is < 35 degrees (1). Acetabuloplasty is recomended for patients with flexible triradiate cartilage (to 11 years of age) when posterior acetabular deficiency is present and acetabular index is $>35$ degrees. Osteotomies that free the acetabulum (Steel, Ganz) are indicated in children with cerebral palsy older than 11 years of age only when the articular surfaces of the joint are congruous or become so once the acetabulum has been corrected. Chiari osteotomy is useful in patients with incongruous joints over 11 years old and the shelf procedure is appropriate for adolescents in which no other osteotomy will establish a congruous joint. The global acetabular deficiency, demonstrated by computerized tomographic studies, suggests that redirectional pelvic osteotomies may be unsuitable for such patients because these procedures have the potential to induce posterior hip instability $(1,15)$. We have not seen the posterior hip dislocation or subluxation in any our patient.

Reconstructive surgery has an uncertain outcome for dislocated hips in older patients with no potential for ambulation and a palliative procedure is frequently the only method of choice (11). In our series palliative Schanz osteotomy have provided a pain control, increased range of motion and improved personal hygiene.

\section{Conclusions}

A childhood is the optimal time to intervene to maximize the function of the patient with cerebral palsy. The musculoskeletal treatment of the child prevents future problems with pain and deformity. Hip subluxation develops in response to muscle imbalance (spasticity and contracture of the adductors and flexors of the hip) and bony deformity develops secondary. Primary is correction of this muscle imbalance by soft-tissue release. In the setting of more significant hip subluxation the isolated soft-tissue release is inadequate and osseous surgery is indicated.

\section{References}

1. Chomiak J. Neuromuskulární onemocnění. In: Dungl P., ed. Ortopedie. Praha Grada Publishing, 2005: 319-83.

2. Kalen V, Bleck EE. Prevention of spastic paralytic dislocation of the hip. Dev Med Child Neurol 1985:27:17-24.

3. Kraus J. Dětská mozková obrna. $1^{\text {st }}$ ed. Praha: Grada Publishing, 2005.

4. Miller F, Bagg MR. Age and migration percentage as risk factors for progression in spastic hip disease. Dev Med Child Neurol 1995:37:449-55.

5. Miller F, Cardoso Dias R., Dabney KW, Lipton GE, Triana M. Soft-tissue release for spastic hip subluxation in cerebral palsy. J Pediatr Orthop 1997:17:571-84.

6. Onimus M, Allamel G, Manzone P, Laurain JM. Prevention of hip dislocation in cerebral palsy by early psoas and adductors tenotomies. J Pediatr Orthop 1991: 11:432-5.

7. Pope DF, Bueff HU, DeLuca PA. Pelvic osteotomies for subluxation of the hip in cerebral palsy. J Pediatr Orthop 1994:14:724-30.

8. Presedo A, Oh CW, Dabney KW, Miller F. Soft-tissue releases to treat spastic hip subluxation in children with cerebral palsy. J Bone Joint Surg 2005: 87-A: 832-41

9. Reimers J. The stability of the hip in children. A radiological study of the results of muscle surgery in cerebral palsy. Acta Orthop Scand Suppl 1980:184:1-100

10. Root L, Laplaza FJ, Brourman SN, Angel DH. The severely unstable hip in cerebral palsy. Treatment with open reduction, pelvic osteotomy, and femoral osteotomy with shortening. J Bone Joint Surg 1995: 77-A:703-12.

11. Schejbalová A. Paliativní Schanzova osteotomie při nereponibilní luxaci kyčelního kloubu u pacientů s dětskou mozkovou obrnou v adolescentním věku. Acta Chir Orthop Traum Čech 2004:71:281-7.

12. Sharrard WJW, Allen JMH, Heaney SH, Prendiville GRG. Surgical prophylaxis of subluxation and dislocation of the hip in cerebral palsy. J Bone Joint Surg 1975: 57-B:160-6.

13. Turker RJ, Lee R. Adductor tenotomies in children with quadriplegic cerebral palsy: longer term follow-up. J Pediatr Orthop 2000:20:370-4.

14. Vojta V., Peters A. Vojtův princip. Praha: Grada Publishing, 1995.

15. Zimmermann SE, Sturm PF. Computed tomographic assessment of shelf acetabuloplasty. J Pediatr Orthop 1992:12:581-5.

Submitted September 2006. Accepted October 2006.

\section{Corresponding author:}

MUDr. Pavel Šponer, PhD., University Hospital Hradec Králové, Department of Orthopaedic Surgery, Sokolská 581, 50005 Hradec Králové, Czech Republic, e-mail: sponer.p@seznam.cz 